\title{
A TREATISE ON
}

\section{THE CONFLICT OF LAWS \\ OR}

PRIVATE INTERNATIONAL LAW

BY

JOSEPH HENRY BEALE

ROYALL PROFESSOR OF LAW IN HARVARD UNIVERSITT

VOL. I. - PART I.

CAMBRIDGE

HARVARD UNIVERSITY PRESS

1916 
COPYRIGHT, I 9 I 6

BY JOSEPH H. BEALE 
TO MY WIFE 
